Studia i Materiały, 1/2018 (26): 117-126

\title{
The Development of Entrepreneurship at a Research University
}

\begin{abstract}
Maksym W. Sitnicki*
The urgency of the study arises from the need of research universities to implement the results of their scientific research into practice in an entrepreneurial business environment and further contribute the resulting financial returns to solving urgent problems of humanity. This article intends to identify the unique features of a person who possesses entrepreneurial skills and to contribute to make a further investigation on his/her potential. It will then become the basis for the construction of a human-centered model of entrepreneurship development at a university conducting research. To study the problem a model is used that takes into account the key processes of entrepreneurial development. The article proposes the definition of a new management category "entrepreneurial progressivism". This reflects the essence of the process of university entrepreneurship development and defines the phenomenon of free innovative thinking in a comprehensive manner. The author also develops a human-centered model of entrepreneurship development and presents and discloses the properties of unique features that are inherent for people with an entrepreneurial bent of mind. This then justifies the interdependence between the success of a research university and the success of its alumni, known as innovative entrepreneurs. The study has a practical value for executives who are interested in improving the university's efficiency and carries significance through the development of entrepreneurial potential.
\end{abstract}

Keywords: "entrepreneurial progressivism", entrepreneurship development, research university, features of an entrepreneur, human-centered model of entrepreneurship development.

Submitted: 10.05 .17 | Accepted: 26.02.18

\section{Rozwój przedsiębiorczości na uczelni badawczej}

Artykut powstat na bazie konieczności praktycznego wdrażania wyników badań naukowych $w$ biznesie przez uczelnie badawcze, których korzyści finansowe z tego tytułu powinny również przyczyniać do rozwiazywania naglacych problemów ludzkości. Celem jest identyfikacja specyficznych cech osób o umiejętnościach przedsiębiorczych oraz wktad $w$ dalsze analizy ich potencjatu. Stanie się to podstawa do budowy skoncentrowanego na człowieku modelu rozwoju przedsiębiorczości na uczelni badawczej. W celu zbadania problemu zastosowano model uwzględniający kluczowe procesy rozwoju przedsiębiorczości. W artykule zaproponowano definicje nowej kategorii zarzadzania - „progresywizmu przedsiębiorczego”. Odzwierciedla ona istote procesu rozwoju przedsiębiorczości na uczelni i kompleksowo określa zjawisko swobodnego myślenia innowacyjnego. Autor prezentuje także model rozwoju przedsiębiorczości skoncentrowany na człowieku oraz specyficzne cechy osób o skłonnościach przedsiębiorczych.

\footnotetext{
Maksym W. Sitnicki, PhD - Taras Shevchenko National University of Kyiv.

Correspondence address: Taras Shevchenko National University of Kyiv, Volodymyrska str., 60, Kyiv, Ukraine, 01033; e-mail: maksym.sitnicki@ukr.net, ORCID: http://orcid.org/0000-0002-0452-0404.
} 
Następnie uzasadnia wspótzależność między sukcesem uczelni badawczej a sukcesem jej absolwentów, określanych mianem innowacyjnych przedsiębiorców. Opracowanie ma praktyczna wartość dla przedstawicieli kadry kierowniczej, którzy sa zainteresowani poprawa efektywności uczelni, oraz istotne znaczenie z perspektywy rozwoju potencjału przedsiębiorczego.

Słowa kluczowe: „progresywizm przedsiębiorczy”, rozwój przedsiębiorczości, uczelnia badawcza, cechy przedsiębiorcy, model rozwoju przedsiębiorczości skoncentrowany na człowieku.

Nadesłany: 10.05.17 | Zaakceptowany do druku: 26.02.18

JEL: M130

\section{Introduction}

The relevance of university entrepreneurship development is based on the need to implement the results of its research and development. Such implementation enables the commercialization of results and ensures a stable income that secures its financial autonomy. The development and popularization of the spirit of entrepreneurship is one of the key tasks of a modern research university. Generally, a traditional university focuses mainly on didactic and scientific activities and entrepreneurship takes the second place. In fact, most universities are fixated on broadcasting knowledge. They invest a great deal of financial resources into the development of their broadcast channels. Such an approach fails to realize the fact that this knowledge may not be used by a graduate when implementing his entrepreneurial idea and starting a new business. Research universities should not only impart knowledge, but also teach methods for their effective use. If this is not the case, then there is a strategic gap between the qualifications of a trained specialist and his real ability to apply his competencies. This is imperative in terms of making a businessman capable of creating new jobs rather than looking for a job.

The need for such a direction of development is underlined by the long-term trends of 2008-2014 which attest to a high unemployment rate in the European Union in comparison with other countries of the world.

Figure 1. Unemployment rates in the OECD, gap between younger and older workers 2008-2014 and differences by country in 2014

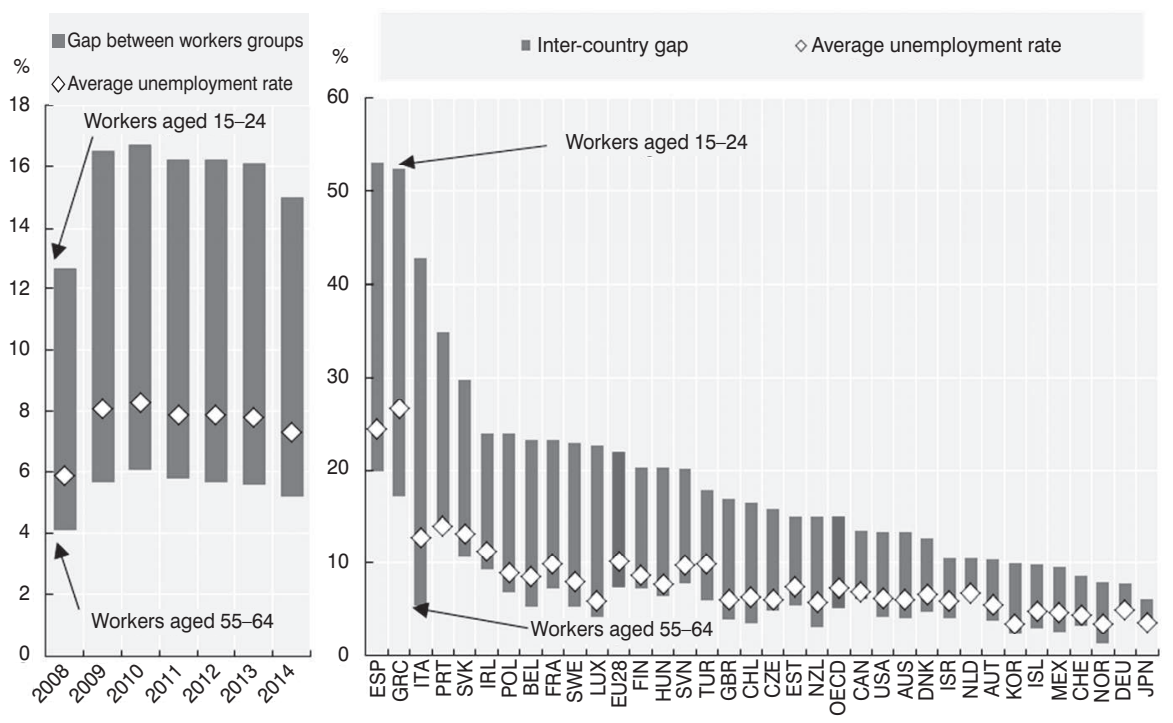

Source: $h$ ttp://dx.doi.org/10.1787/888933272781 
Re-employment is becoming widespread and proliferates when the unemployment rate decreases in most countries, including those most affected by the 2008 financial crisis (OECD, 2015). The unemployment rate in the OECD countries fell by 1.6 percentage points, postwar, maximum of $8.5 \%$ in October 2009 . It then dropped to $6.9 \%$ in April 2015, when the average unemployment rate in the European Union remained at almost $10 \%$. However, the most disturbing trend in terms of strategic perspective is the unemployment rate of youth. It remains low, especially in Europe, where the average unemployment rate for young workers (aged 15-24 years) exceeds $20 \%$ and more than $40 \%$ for Spain, Greece and Italy. The growth of employment in different groups has changed dramatically during the recovery period. Unemployment rates for women are somewhat higher than men. Research institutes are supposed to find a remedy for this problem through extensive entrepreneurial development and its popularization among young people.

\section{Literature review}

What follows are the results of the research done by the modern authoritative scientists who made significant contributions to the development of entrepreneurship in their comprehensive studies. Authors (Pasieczny and Glinka, 2008) note the importance of analyzing administrative errors for the development of entrepreneurs. This fundamental work explains why the managers who work under uncertainty often do not or cannot use the existing examples and experience of others including their own. The authors provide the examples of the most common mistakes of managers, along with the implications to the management of organizations' development.

The subsequent work (Pasieczny, 2011) describes the impact of the global crisis and the way it influenced business entrepreneurs. During the global crisis, many Polish companies had to resort to different strategies in order to be able to continue running their businesses. These strategies included finding new markets, reorganizing existing processes, changing product range, and transforming the employment structure. The author noted valuable experience, behavioral scenarios and lessons learned from successes and failures for further consideration in entrepreneurial practice.

In his scientific work, Romanovsky (2012), studies the activities of leading universities in the United States, Britain and other economically developed countries. Attention is paid to the phenomenon of a university (academic) entrepreneurship program and its influence on the economic development of different countries. It also considers the origin of academic capitalism and the consequences of university commercialization. The work likewise looks at the concepts and models of the "triple spiral" developed by G. Itskovits and the possibility of their use for the innovative development of Ukrainian society. In this paper, the author emphasizes the timeliness of university entrepreneurial development as a way to the harmonious development of a country.

A Polish economist, Sztompka (2016), emphasized that universities, unlike vocational schools, should educate bright citizens, not just skilled workers. The emphasis should be on practical skills and narrow specializations, as key components of democratic development.

Author (Kubera, 2017) studied the relationship between normative frameworks and entrepreneurship that is based on three scenarios: the law can promote it, inhibit it, or be neutral in this respect. The author shows how an impact assessment can lead to a better legislative environment for new business innovations. The scholar, also, revised the approaches to the impact assessment applied in Poland and other OECD and EU countries. He made a comparison between different states outlining the challenges faced when implementing regulatory impact assessments.

Zygmunt (2017) identified the most important determinants for the development of enterprises in the most remote regions regarding specific models of regional development. The study shows the need to introduce innovations in the areas of knowledge transfer and the development of social and human capital in regions that do not have sufficient endogenous resources. The work emphasizes on the promotion of internationalization and cooperation. It is aimed at using the opportunities of market formation and its benefits for the development of entre- 
preneurial innovations. The author also emphasizes the importance of supporting entrepreneurial thinking, especially among the younger generation.

The results presented by Rostek i Skala (2017) consists of the first Polish study of startups that are gaining increasing importance in the country's economy and considered as a source of entrepreneurial innovations. This scientific work defined and characterized the population of economic entities recognized according to the criteria used for the Polish start-up companies. For this purpose, a database of these objects was created, and then opinion polls and a nationwide questionnaire survey were carried out in cooperation with the Startup Poland Foundation. The segmental analysis allowed identification of distinct classification groups and the relevant characteristics of each of them. The discussion of the role and meaning of time in the process of internationalization of enterprises became the main subject of research (Daszkiewicz, 2017) in the field of internationalization. Based on two main theoretical approaches and its empirical verification, the author presented the problem of speed with regard to the process of enterprises' internationalization The work also presents the results of research on 263 international companies working in the field of high technologies in Poland.

A detailed study of the phenomenon of entrepreneurship is central to this scientific work (Chmielecki i Sułkowski, 2017). The authors explained the theoretical foundation of a metaphor which was used for better understanding of entrepreneurship. They also provide a new, cognitive approach to the definition of 'an entrepreneur' that distinguishes entrepreneurs and non-entrepreneurs. This research gives an idea of the entire field through the prism of images, or metaphors used both among entrepreneurs and non-entrepreneurs. It also provides the definition of an entrepreneur based on the responses received from a survey of 124 participants.

The Indonesian peculiarities of entrepreneurial development were presented in a scientific work conducted by Sunanto, Gunawan, Gunawan i Dijk (2017). The authors emphasize the importance of developing people with entrepreneurial mind set to work in politics and science due to their capability to contribute signifi- cantly to the success of small and mediumsized enterprises in Indonesia. The study covers issues related to female entrepreneurs and their views on a wide range of areas. This includes their readiness to take business risks, as well as participation in the development of the local economy. It also included the areas of self-efficacy and perceptions of opportunities. Lastly, it studied what it took to be a model for others to imitate and their fear of failure. Data was collected from 5620 respondents of different provinces, both rural and urban areas of Indonesia. In order to get a better idea of the position of women in terms of entrepreneurial analysis, the data analysis was conducted using a descriptive method by developing facts and graphs.

Pelle i Végh (2017), comprehensively analyzed competition and competitiveness in the EU internal market both at EU level and in its member states. The main analytical tool used three indicators developed by the authors on the basis of the data and methodology of the World Economic Forum. These indicators serve to measure the competitiveness of 1) state, 2) business sector and 3) market institutions of EU member states. The Global Entrepreneurship Development Institute (GEDI) indicator was used to assess entrepreneurial activity. The results were then summed up in two dimensions. Without a doubt, the member states are divided into two groups according to all indicators; central and peripheral. It is noted that all countries of the Visegrad region, in relation to the development of entrepreneurship, belong to the peripheral group, but it is worth analyzing their relative positions within the group.

The current issue of migration in modern times and its impact on the development of entrepreneurship in Europe is indicated in the study conducted by Kwieciński and Matusz-Protasiewicz (2017). It has been determined that migrants and immigrants are present in the European labor market both as workers and self-employed entrepreneurs. The role and importance of entrepreneurship among migrants is changing. At present, migrants are beginning to work in sectors other than the traditional ones like retail, hotel and catering. Interestingly, the second generation of migrants born in destination countries, regardless of whether they continue working in pri- 
vate business of their parents or not, base their businesses on social and developed capital ties. These are formed between the state where they live and the country of their origin providing the opportunity for broad cooperation. Immigrants are becoming increasingly important for new markets in economically developed countries. The study proposes a systematic approach to ethnic entrepreneurship.

The research undertaken by Ribeiro, Fernandes, Cabo and Matos (2017) investigates the essence of an entrepreneur as a person, and business, as an object of management. In their view, it involves creating new structures and developing new business opportunities in existing organizations. The work also attempts to understand the perception and attitude of Portuguese students pursuing higher education and their perception towards creating a new business The study was conducted in 2014 and 2015 , with a random sample of 336 students. Data analysis was performed using SPSS 22.0. The survey found that respondents believed that entrepreneurship contributes to the creation of new working places and employment generation. $46 \%$ of respondents could imagine creating their own business. $47 \%$ of students saw a high likelihood of being able to create a successful business by the age of 28. Approximately $49 \%$ of respondents were interested in creating a new company, mainly because it allows personal independence. Moreover, in spite of high optimism about the level of survival of new enterprises, students exhibit low activity.

\section{Methodological Framework}

The main objective of this analysis is the systematization of the entrepreneurship development process in a university by applying a modeling method. According to the objectives, the article discloses the following: 1) proposes a new management category of "entrepreneurial progressivism", which reflects the essence of the process of university development and provides complete insight into the freedom of innovative thinking; 2) develops a human-centered development model to systematize this process; 3 ) presents and reveals the properties of the unique features inherent in people with an entrepreneurial mindset; 4) substantiates the inter- dependence of the university's success and the success of its graduates who became innovative entrepreneurs. The following scientific methods were used during the research 1) empirical method and method of generalization, which provided knowledge about the external aspects of creative people distinguished by their entrepreneurial aptitude in research-based universities; 2) a method of comparison to identify qualitative and quantitative characteristics of approaches to business development in leading universities in the world; 3 ) methods of analysis, synthesis, formalization and deduction in the process of perception and reflection of the detailed essence of the process of entrepreneurial development in a university.

\section{Results}

For the successful development of the entrepreneurship it is first necessary to change the way creative young people study and do research at the university. Immediately upon entering the university, they should be oriented towards self-promotion of their own entrepreneurial ideas. This should be their process instead of searching for those who can sell ideas without their further development. Those personalities, who are capable of creating new and innovative ideas and fight for them, should be given special attention in universities. All their initiatives should be supported at the initial stages, because those with an entrepreneurial mindset are very vulnerable to criticism. They tend to have a high degree of doubt in their ideas and developments. They strongly believe in their dreams and know what they want, but often lack confidence in how to get the results and bring them to life. If a brilliant idea is not recognized right away, it may be lost without giving it a chance to become a key solution for resolving important tasks. The condition of freedom of thought and a sense of comprehensive support is ensured by academic freedom. It should be ideally promoted as a key principle in operations of each university with a research orientation.

Academic freedom - is the self-sufficiency and independence of participants in the educational process during the conduct of pedagogical, scientific and pedagogical, scientific and / or innovative activities. All these activities must be carried out on the 
principles of freedom of speech, thought and creativity, and the dissemination of knowledge and information. This must also be augmented by free publication and the use of scientific research findings with consideration to the restrictions established by law (Law of Ukraine "About education", 2017).

However, in order to fully characterize the process that guarantees freedom of thinking, creation, and independence for participants, we introduce a new managerial category that might be defined as "entrepreneurial progressivism" into scientific circulation and will reveal its meaning.

Entrepreneurial progressivism - is a process of development based on academic freedom and a set of principles that guarantee the implementation of scientific ideas of a person with an entrepreneurial mindset. It provides for realization of business approaches, opportunities to act freely and in a non-standard way, and being creative and rational. It still prevails even if the institution in which the person operates possesses an opposite view.

The proposed definition of the university development process is focused in a way which reflects the foundationalism of a human-innovator in the university's activities in the manner in which it is encouraged in the leading universities.

If you look at the practice of business development at Oxford University, one has to pay attention to the level of its expenditures on the development of the innovative business environment potential (University of Oxford: Finance and funding, 2016). The staffing expenses accounted for around $£ 680.3$ million in the fiscal year 2015-2016 which is about $51 \%$ of the total expenses of $£ 1336.5$ million. There is a clear assertion that investing into people is a major priority for Oxford University. This gives it the opportunity to be one of the world's best research universities.

In one of the best research universities in the United States, Stanford University, wage and salary costs accounted for $59 \%$ of the university's total expenditures in the fiscal year, 2016-2017 (Stanford University: Administration \& Finances, 2017).

The validity of this path of development is confirmed by the figures that indicate the largest number of Nobel laureates in these universities: 1st place - the United States of America; 2nd place - United Kingdom; 3rd place - Germany; 4th place - France; 5th place - Sweden; 6th place - Switzerland; 7th place - USSR-Russia; 8th place - Austria; 9th place - Canada; 10th place - The Netherlands (The Official Web Site of the Nobel Prize, 2017).

Consequently, the strategy of entrepreneurial development within a university, focusing on research, should be based on the priority development of its employee's innovative potential. This sets forth the creation of necessary material, along with ideological motivators to support each rational initiative. As for creative people, it is necessary to constantly observe them. There should be a constant awareness of the methods, style and the ways and tasks they use to solve problems. All this should be done with the purpose of full disclosure of their potential, and the timely identification of key ideas.

Entrepreneurial progressivism in a research university is a unique phenomenon. It is formed by creative people who are characterized by special behavioral features.

\section{Behavioral features of a person with an entrepreneurial type of thinking}

We distinguish the main behavioral features of a person with an entrepreneurial style of thinking as someone possessing a significant innovative potential. Based on our own empirical observations, we recognize the following features:

1. Faithfully believes in the reality and true meaning of his/her idea.

2. Multi-tasks and performs complex operations.

3. Is in the constant process of experimenting.

4. Does not look for an easy way and always searches for alternatives.

5. His/her behavior and way of thinking surprises others.

6. After entering university he/she does not see clearly which direction of training corresponds to his/her interests, and may subsequently lose curiosity. 
7. Cannot immediately appreciate the results of his/her intellectual work.

8. Able to sacrifice private life for the implementation of entrepreneurial ideas.

9. Has a sharply developed sense of demand, and resultant desire to satisfy it.

10. Aspires to maintain constant selfimprovement and development of his/ her ideas.

11. Very observant, thus often sees what others do not see.

12. Feels as if born to change the world

These features mainly reflect a character and a style of behavior of an entrepreneur-innovator. We express this conviction that the successful research activity of a world-class university depends on such people. This interdependence of success is expressed in an image and material bonuses. These are what a university gains when it manages to help an entrepreneur to implement his/her business plan successfully.

For example, this year, a graduate of the Wharton Business School at the University of Pennsylvania in the United States, received a job at a New York based firm managing private assets, and was offered the highest starting salary of $\$ 350,000$ a year. Of course, the PR that the university received and those image bonuses are difficult to measure. This story was brought into public focus by very well-known specialized media of the world, causing a wave of interest.

Another example came at the end of 2015. Harvard University graduate, Mark Zuckerberg announced his decision to invest $99 \%$ of his Facebook stock into the development of personalized education, health improvement and modernization of communication between people.

Elon Musk is an another example who will long continue to be the object of thorough scientific analysis and reflection. This amazing founder of projects such as X.com, PayPal, SpaceX, Tesla Motors, Hyperloop, SolarCity and others, is the head of the Musk Foundation. In January 2015, the Foundation donated $\$ 10$ million to the
Institute of Future Generations to study artificial intelligence control. In December 2016, he became a member of the Presidential Strategy and Policy Forum (Strategic and Policy Forum) under US President Donald Trump. They are a group of 16 American entrepreneurs whose job is to advise the 45th US President on issues related to economic growth, job creation, and productivity. This is a vivid example of a person with entrepreneurial thinking who was born into an entrepreneurial family. During his studies at Stanford University, Elon Musk had already envisioned his dreams of implementing a further concept of human development. Despite his failures and defeats, he succeeded in the realization of his entrepreneurial ideas, and now has become a person capable of influencing business development in the United States and around the world.

These examples strengthen our belief in a necessity to develop the innovative potential of people. All programs, at all university levels, should be aimed at building a human-centered model of a research university. This should be a model which strongly supports entrepreneurial ideas from their very beginning. This vision was supported by a group of scientists from the five leading universities which focus on research in Ukraine. It was done with the help of the doctrine of sustainable development of Ukraine for a strategic perspective until 2030 (Zhylinska, Melnychuk and Antonyuk, 2017). This document highlights the idea of successful development of Ukraine as a whole on the path to the European Future. However, the details of working towards the implementation of entrepreneurship in the walls of these universities remained outside the scope of this important document.

In our study, we want to develop this direction and offer our own vision of entrepreneurial progressivism at the university level. Our approach is based on the concept of building a human-centered model of development in these universities that will provide a comprehensive understanding of the system processes, principles, and conditions. 
Figure 2. A human-centered model of entrepreneurship development at a research university

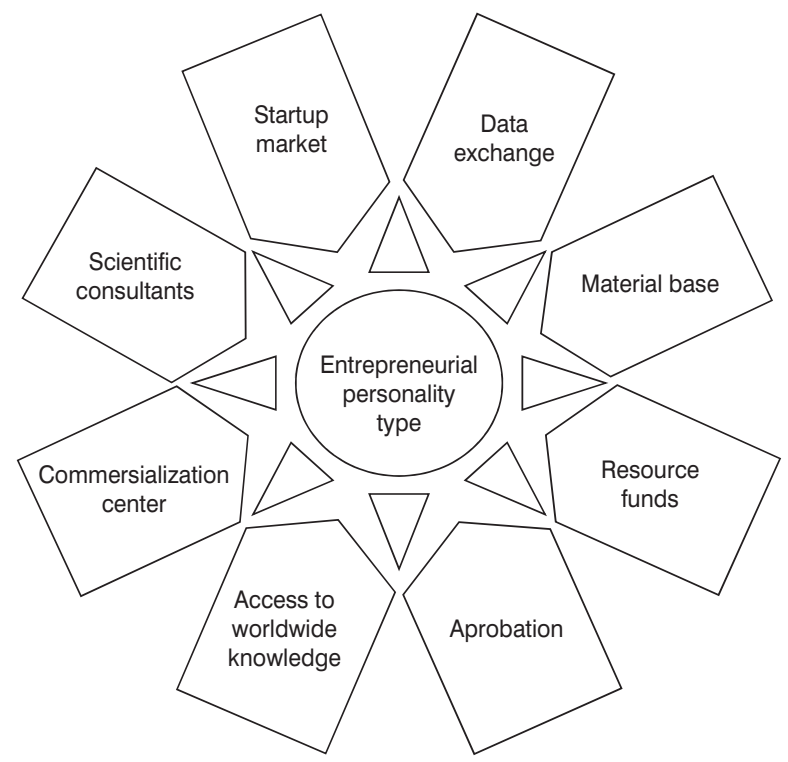

Source: developed by the author.

The indicated model in Figure 2, consists of eight elements and provides a comprehensive opportunity to make entrepreneurial progressivism work. We further examine the essence of this model, giving details of its components.

1. The startup market - A research university should actively participate in the open market where it can sell the technologies of their entrepreneurs. It is clear that a university is not capable of putting the entire volume of ideas into practice by producing new products. Nevertheless, having implemented some of them, it will receive a financial resource to invest into the most important projects in accordance with its implementation of strategic goals.

2. Data exchange - This element is valuable in terms of the necessity to have a constant flow of fresh scientific and technical information and thus transmitting it from its own sources. This increases the possibility of involving leading scientists, specialists and practitioners in solving a certain business problem or inventing a technological solution. To ensure such cooperation, there are already widely used social networks of scholars and scientific institutions of various profiles. These exists with the newly created circles united by entrepreneurial and busi- ness interests. The exchange of business data provides valuable experience and generates ideas, as well as enables the formation of a positive university image in professional, scientific and entrepreneurial circles.

3. The material base - The provision of collaborating an entrepreneur and a social scientist with qualitative experimental equipment should become a priority of any university conducting research. The university should raise money from regional funds to develop education and science and use opportunities related to international technical assistance for the continuous improvement and development of its material base. A contemporary entrepreneur-innovator will only be efficient if he/she has an access to stateof-the-art technology.

4. Resource funds - Let us focus on the fact that financing of entrepreneurial activity carries a large share of risks and unsecured expectations. Investment funds are not always ready to provide financial support to a young entrepreneur. For this purpose, the university should operate a subdivision of cooperation with venture funds. This should be done along with the opportunity to search for alternative sources of financing for business progressivism. In this case, 
persuasive arguments should be readily available. A clear business plan will help the potential investor to see a possibility of returning his investment and getting profits. Of course, venture funds do not invest in all projects. They are not very interested in high-risk projects as there is a high chance of failure. Usually, $70-80 \%$ of projects do not bring rewards, but the profit from the remaining $20-30 \%$, pays off all the losses.

5. Approbation - When the product or technology is created, the next important step to be carried out is its testing. This is done either on the specialized / customer focus groups, or on a wider scale. Unfortunately, this issue is not usually given much attention, but one cannot underestimate its importance. High quality testing may prevent future financial losses due to its false diffusion into the broad market. Obviously, its worth spending some money on testing or preparatory stage than to lose much more later.

6. Access to worldwide knowledge - Every self-respecting research university should ensure open access of all possible science metrics and other sources of information on the world achievements, to anyone who needs it. It is specifically important for an entrepreneur to avail this opportunity to conduct preliminary theoretical investigation of his project, product or technology.

7. Commercialization center - This facility registers the entrepreneur's idea. The introduction of a particular business to a market requires financial resources. It also requires the strong ability to analyze the market correctly, to develop a strategy of how to fit in, and calculate the risk. You must study the political, economic and social factors that will demonstrate the readiness of society to accept the products. You likewise have to be able to carry out many marketing and promotional activities. It is also necessary to consider the logistics and delivery of the product to a consumer. In some cases this accounts for $20 \%$ of the total value of a product and thus requires a balanced analytical approach to its construction. People innovators do not always have the necessary competence to do all this work on their own. A university research department plays an important role in terms of supporting a young inventor. It should give him the opportunity to be fully involved in the process of creating and improving his products.

8. Scientific consultants - There is a misconception in the society that scientists are not able to manage business and can deal only with theoretical issues. This idea is false in its very nature. An entrepreneur's profound knowledge of the theory of a particular process can lead him to making a rational decision or improving/creating an alternative product. Therefore, not having sufficient theoretical knowledge forces an entrepreneur to refer to scientific advice or a detailed explanation of the theoretical substantiation of a particular phenomenon or process. A university should create formal and non-formal platforms for such kind of communication in order to exchange ideas and create highly specialized interest groups. This should include graduates of the university's business school.

\section{Conclusions}

Having explored the processes of entrepreneurship development in a research university, 12 unique features of a person with a business mindset were revealed and a man-centered model of entrepreneurship development at a research university was designed. Furthermore, following the research on a planning of the business development process at a research university, we obtained the following scientific results. Firstly, a new administrative category as "entrepreneurial progressivism" was proposed. It comprehensively reveals the essence of the process of entrepreneurship development in a university conducting research and the phenomenon of freedom of innovative thinking. This concept enriches the categorical apparatus for further investigation of entrepreneurship and will give impetus to rethink its significance in modern technological conditions.

Secondly, according to the results of the empirical research, the properties or unique features that are inherent to people with an entrepreneurial type of thinking were identified and presented. These features show the refinement of creative people and their particular attitude to their 
surroundings. Also, it provided concrete examples of the world's successful businessmen that showed the interdependence between the success of universities, and the success of its graduates who become innovative entrepreneurs.

Thirdly, a human-centered model of entrepreneurial development in a university was introduced. It systematizes the necessary elements for ensuring the continuous reproduction of innovative ideas of entrepreneurs within the walls of a university which focuses on research. A detailed description shows the functional purpose of each of them. The development of entrepreneurship is the development of the model's internal elements - the grounds and preconditions for production and business - their materialization and further commercialization. Taking into account the promptness of technical development, modern economic systems require effective managers with a global and entrepreneurial mindset. The developed model will enable systematization of the training process of such specialists, capable of solving problems of modern business environment.

\section{References}

Chmielecki, M. and Sułkowski, Ł. (2017). Obrazy przedsiębiorców - wyniki badań własnych. Problemy Zarzadzania, 1(65), 151-163, http://doi. org/10.7172/1644-9584.65.9.

Daszkiewicz, N. (2017). Tradycyjna versus przyspieszona internacjonalizacja przedsiębiorstw z branż high-tech. Wyniki badań empirycznych. Problemy Zarzadzania, 1(65), cz. 1, 164-175, http://doi. org/110.7172/1644-9584.65.10.

Kubera, P. (2017). Ocena wpływu regulacji i polityki regulacyjnej na rzecz lepszego ekosystemu przedsiębiorczości. Przypadek Polski. Problemy Zarzadzania, 1(65), cz. 1, 237-253, http://doi. org/10.7172/1644-9584.65.15.

Kwieciński, L. and Matusz-Protasiewicz, P. (2017). Przedsiębiorczość etniczna jako proces wielowymiarowy w kontekście analizy systemowej. Problemy Zarzadzania, 1(65), cz. 1, 97-109, http://doi. org/10.7172/1644-9584.65.6.

Law of Ukraine «About education» (2017). 2145-VIII. Pozyskano z: http://zakon2.rada.gov.ua/ laws/show/2145-19 (15.10.2017).
OECD Science (2015). Technology and Industry Scoreboard, http://dx.doi.org/10.1787/sti scoreboard-2015-en.

Pasieczny, J. (2011). Nauka czerpana z kryzysu - perspektywa przedsiebiorstw. Problemy Zarzadzania, 1, 257-274.

Pasieczny, J. and Glinka, B. (2008). Błedy menedżerskie - wybrane źródła i implikacje dla rozwoju. Problemy Zarzadzania, 4, 151-169.

Pelle, A., Végh, M. (2017). Entrepreneurship and Competitiveness in the EU Member States, with Special Regard to the Visegrad Countries. Problemy Zarzadzania, 1(65), cz. 1, 13-32, http://doi. org/10.7172/1644-9584.65.1.

Ribeiro, M., Fernandes, A., Cabo, P. and Matos, A. (2017). Przedsiębiorczość i tworzenie nowych przedsiębiorstw: postrzeganie, zachowania i postawy studentów portugalskiej wyższej uczelni. Problemy Zarzadzania, 1(65), cz. 1, 129-150, http:/ doi.org/10.7172/1644-9584.65.8.

Romanovsky, O. (2012). The phenomenon of entrepreneurship at the world's universities. Vinnitsa, New Book.

Rostek, K. and Skala A. (2017). Kryteria różnicujące i segmentacja polskich przedsiębiorstw startupowych. Problemy Zarzadzania, 1(65), cz. 1, 192-208, http://doi.org/10.7172/1644-9584.65.12.

Stanford University: Administration \& Finances. (2017). http://facts.stanford.edu/administration/ finances (17.10.2017).

Sunanto, S., Gunawan, A., Gunawan, T. and Dijk., M. (2017). Women Entrepreneurs: A Study of Indonesian Female Evidence and Perception for Becoming Entrepreneurs. Problemy Zarzadzania, 1 (65), cz. 1, 110-149, http://doi.org/10.7172/16449584.65.7.

Sztompka, P. (2016). Uniwersytet w przestrzeni społecznej. Zarzadzanie Publiczne, 2(36), 55-58, http:// doi.org/ 10.15678/ZP.2016.36.2.03.

The Official Web Site of the Nober Prize (2017). https://www.nobelprize.org, (10.10.2017).

University of Oxford: Finance and funding (2017). https:/www.ox.ac.uk/about/organisation/financeand-funding?wssl=1 (17.10.2017).

Zhylinska, O., Melnychuk, O. and Antonyuk, L. (red.) (2017). Ukraine 2030: Doctrine of sustainable development. Lviv: Kalvaria.

Zygmunt, J. (2017). Rozwój przedsiębiorstw w regionach peryferyjnych: wzorce i determinanty. Problemy Zarzadzania, 1(65), cz. 1, 226-236, http:// doi.org/10.7172/1644-9584.65.14. 